\title{
Age of Majority
}

National Cancer Institute

\section{Source}

National Cancer Institute. Age of Majority. NCI Thesaurus. Code C126362.

The age at which a minor assumes legal control over their person, actions, and decisions. 